УДК $323.22+329.7$

DOI 10.25205/978-5-4437-1268-0-52-54

\title{
С.И. Филиппов
}

Новосибирский государственный университет, Новосибирск, Россия

\section{ПРОТЕСТЫ В СССР И КНР В КОНЦЕ 1980-Х - НАЧАЛЕ 1990-Х ГГ.}

Исследование посвящено анализу динамики успеха протестных движений на материале истории позднего СССР (конец 1980-х - начало 1990-х гг.) и событий на площади Тяньаньмэнь в Пекине в 1989 г. Показателями успеха протестных движений являются переход элит на сторону протестующих, а также существенные (гео)политические трансформации в обществах, где разворачиваются протестные движения. Анализ проводится на материале сопоставления контрастных случаев: относительно успешных протестных движений в советских республиках Прибалтики (1987-1991 гг.) и Москве (август 1991 г.) - с одной стороны - и неуспешных выступлений - демонстрации казахского студенчества в Алма-Ате в декабре 1986 г., а также волнений молодежи в Пекине, продолжавшихся с апреля по июнь 1989 г. Успех протестов объясняется антимиграционной идеологической альтернативой официальной интернационалистской доктрине сформулированной оппозицией и обладающей высокой привлекательностью для самых разных социальных и этнических групп населения в случае Прибалтики и неприменением насилия в отношении протестующих в Москве, что стало существенным фактором, способствующим росту протеста. Неуспех молодежных выступлений в Алма-Ате и Пекине объясняется тем, что они воспринимались в логике молодежной агрессии, вызывая страх и отторжение как у элит, так и у населения (соответственно, как продолжение территориально-этнических конфликтов в случае Алма-Аты и как опасность широкомасштабного насилия в стиле культурной революции - в случае Пекина).

Ключевые слова: протест, элиты, лояльность, СССР, КНР

\section{S. I. Filippov}

Novosibirsk State University, Novosibirsk, Russia

\section{PROTESTS IN THE USSR AND CHINA IN THE LATE 1980s - EARLY 1990s}

The research deals with investigation into the conditions of the success of protest movement on the basis of the history of the late USSR (late 1980s - early 1990s) and the Tiananmen Square protests in Beijing in 1989. The defection of the elites to the protesters, as well as significant (geo)political transformations in societies where protest movements take place, are considered indicators of the success of protest movements. The analysis is based on comparing contrastive cases - relatively successful protest movements in the Soviet republics of the Baltic (1987-1991) and Moscow (August 1991) on the one hand as well as unsuccessful cases such as the demonstration of Kazakh students in Alma-Ata in 
December 1986 and youth protests in Beijing which lasted from April to June 1989. A broad support of the protest movement striving for the reestablishment of the independence from the Soviet Union was based in the case of the Baltic republics on anti-immigration ideological alternative to official Soviet internationalism attracting different social and ethnic groups of Latvian population. As for Moscow, the non-use of violence against protesters was a significant factor that contributed to increasing street demonstrations in the capital of the Soviet Union. A relatively low social support of the protest movement in Kazakhstan was due to the lack of a broad ideological basis that could create solidarity between different social and ethnic groups that made up the population of Kazakhstan. Besides, the riots in Alma-Ata in 1986 with Kazakh students as main participants were perceived by local population as well as elites in the logic of ethno-territorial conflicts very common in late Soviet Kazakhstan and evoked therefore not solidarity but fear and anger. Similar reaction was evoked by the Tiananmen Square protests in Beijing in 1989 that resembled the surge in youth violence during the Cultural Revolution.

Keywords: protest, elite, loyalty, USSR, China

Исследование посвящено анализу динамики успеха протестных движений на материале истории позднего СССР (конец 1980-х - начало 1990-х гг.) и событий на площади Тяньаньмэнь в Пекине в 1989 г. Анализ проводится на материале сопоставления контрастных случаев: относительно успешных протестных движений в советских республиках Прибалтики, кульминацией чего выступили события в Вильнюсе и Дни баррикад в Риге (январь 1991 г.), а также противостояние ГКЧП и протестующих в Москве (август 1991 г.), за которыми последовали существенные (гео)политические трансформации и протестных выступлений, которые были достаточно эффективно подавлены и не привели к существенным политическим переменам, тем более, к смене режима, при этом консервативные силы упрочили свое влияние - выступления казахской молодежи в Алма-Ате в декабре 1986 г. («Желтоксан») и молодежных протестов в Пекине, продолжавшихся с апреля по июнь 1989 г. Существенное влияние на степень успешности протестных движений оказывает позиция элит. Если правители (индивидуальные или коллективные) всегда направлены на сохранение status quo, то поведение элит вариативно - они либо сплачиваются вокруг правителя, либо раскалываются с выделением контрэлиты и переходом в стан протестующих [Розов, с. 90]. Действительно, многие представители национальных советских элит прибалтийских республик, в том числе и силовых переходят на сторону протеста, например, независимость Латвии поддержало большинство местной милиции и прокуратуры, а позиция республиканского КГБ оказалась даже более радикальной, чем позиция сотрудников упомянутых двух ведомств [Блейере, 2005, с. 405], сходная ситуация складывается и в РСФСР, в особенности, в Москве, где обостряются противоречия между общесоюзной и республиканской властью, а городские органы власти в столице в начале 1990$\mathrm{x}$ гг. состоят в значительной мере из представителей оппозиции. Казахстан последовательно выступал за сохранение СССР, и республика выходит из его состава последней - 10 декабря 1991 г. В Китае партийно-государственная элита также сохранила лояльность режиму в период противостояния на площади Тяньаньмэнь.

Переход национальных элит республик Прибалтики, прежде вполне лояльных союзному центру, на сторону оппозиции в конце 1980-х - начале 1990-х гг. был обусловлен успехами протестного движения, в том числе, и в силовом противостоянии с его противниками (события в Вильнюсе и «Дни баррикад» в январе 1991 г.). Широкую социальную поддержку протестного движения обеспечила антимиграционная идеологическая альтернатива официальной интернационалистской доктрине, обладающая высокой привлекательностью для самых разных социальных и этнических групп населения Латвии. Специфика Москвы того же периода времени состояла в том, что там, по сравнению с иными очагами протеста действовал своеобраз- 
ный негласный мораторий на применение насилия по отношению к митингам оппозиции, что оказалось фактором, способствующим нарастанию публичного протеста.

Относительно высокая степень лояльности национальных советских элит Казахстана союзному центру вплоть до распада СССР объясняется эффективным подавлением протестных выступлений в декабре 1986 г., что послужило поводом для инициированных Москвой чисток национального партийно-государственного аппарата республики. Относительно низкая поддержка протестного движения объясняется отсутствием объединяющей идеологической альтернативы, а также восприятием протестных акций, социальной базой которых была, преимущественно, студенческая молодежь, местным населением и элитами в логике бытовых территориально-этнических конфликтов.

Отношение элит и населения КНР к выступлениям пекинской молодежи сходно со случаем Казахстана. Протестующие воспринимались, скорее, не как борцы за демократию, а как новые хунвэйбины - провозвестники следующей разрушительной Культурной революцию, вызывая, тем самым, страх и отторжение, а не сочувствие. Кроме того, восставшая молодежь активно апеллировала к международному общественному мнению, что также противоречило нормам традиционной китайской культуры (как и сам феномен молодежного бунта) и только увеличивало дистанцию между протестующими и основной массой населения.

\section{Список литературы}

Блейере Д., Буртулис И., Зунда А. и др. История Латвии, ХХ век. Рига: Юмава, 2005. 474 с. Розов Н.С., Пустовойт Ю.А., Филиппов С.И., Цыганков В. В. Революционные волны в ритмах глобальной модернизации. М.: Красанд, 2019. 408 с. 